\title{
Feto-maternal Outcomes in Cesarean Section Compared to Vaginal Delivery in Eclamptic Patients in a Tertiary Level Hospital
}

\author{
Sheuly Begum ${ }^{1}$, Ferdousi Islam² ${ }^{2}$, Arifa Akter Jahan ${ }^{3}$
}

\begin{abstract}
Background: Over half-a-million women die each year from pregnancy-related causes, and 99 percent of these occur in developing countries. In Bangladesh though maternal mortality rate (MMR) declined significantly around $40 \%$ in the past decade, still eclampsia accounts for 20\% of maternal deaths. Eclampsia is uniquely a disease of pregnancy, and the only cure is delivery regardless of gestational age. A rational therapy for general management of hypertension and convulsion has been established in Bangladesh by the Eclampsia Working Group. But controversy still exists regarding obstetric management. Objective: To evaluate the feto-maternal outcome in cesarean section compared to vaginal delivery in eclamptic patients. Materials and Methods: This prospective cohort study was conducted in the department of Obstretics \& Gynecology, Dhaka Medical College \& Hospital (DMCH), from January to December 2011. A total 100 eclamptic women with term pregnancy and live foetus were purposively included in the study (Group I, 50 patients with vaginal delivery and Group II, 50 with cesarean section). Results: Out of these 100 patients $56 \%$ were aged $<20$ years, $71 \%$ were primigravida and $77 \%$ were from low socioeconomic status. Sixteen percent patients from vaginal delivery group and $18 \%$ from cesarean section group had no antenatal care. The mean gestational age was about 38 weeks in two groups. No significant difference was found between the two groups regarding blood pressure, proteinuria, consciousness level and convulsion. Recurrence of convulsion occurred in $30 \%$ patients of vaginal delivery group compared to $6 \%$ in cesarean section group. Maternal complications such as postpartum hemorrhage, cerebrovascular accident, renal failure, obstetric shock and abruptio placenta were higher among vaginal delivery group patients (46\%) than cesarean section patients $(16 \%)$. Maternal mortality was $6 \%$ in the vaginal delivery group and none in the cesarean section group. Regarding fetal outcome, stillbirth was $20 \%$ after vaginal delivery and $6 \%$ after cesarean section, the result was statistically significant. Birth asphyxia was less in the cesarean section group (23.4\%) than in vaginal delivery group (60\%) and this was statistically significant. Conclusions: The result of the present study shows a better fetomaternal outcome in the cesarean section group than in the vaginal delivery group.
\end{abstract}

Key words: Eclampsia, Cesarean section, Vaginal delivery, Feto-maternal outcome

J Enam Med Col 2013; 3(2): 77-83

\section{Introduction}

Eclampsia is the occurrence of convulsion in association with the features of pre-eclampsia. ${ }^{1}$ Preeclampsia is a multisystem disorder that is usually associated with hypertension and proteinuria. $^{2}$ Eclamptic seizure classically occurs in the second half of pregnancy to 10 days after delivery, but may

1. Assistant Professor, Department of Gynecology \& Obstetrics, Enam Medical College \& Hospital, Savar, Dhaka

2. Professor, Department of Gynecology \& Obstetrics, Dhaka Medical College \& Hospital, Dhaka

3. Associate Professor, Department of Gynecology \& Obstetrics, Kumudini Medical College \& Hospital, Tangail

Correspondence SheulyBegum,Email: showshew@yahoo.com 
occur up to 6 weeks postpartum. ${ }^{1,3}$

Over half-a-million women die each year from pregnancy related causes and $99 \%$ of these occur in the developing countries. In Bangladesh though maternal mortality rate (MMR) declined significantly around $40 \%$ in the past decade, still eclampsia accounts for $20 \%$ of maternal death. ${ }^{4}$

In Bangladesh, the incidence of eclampsia is high (7.9\%) according to the results of a house to house survey. ${ }^{5}$ In the baseline survey of Emergency Obstetric Care (EOC) in Bangladesh, 5\% of total obstetric admissions in health facilities were due to pre-eclampsia and eclampsia. ${ }^{6}$ Eclampsia contributes to $20 \%$ of maternal mortality on a national basis. Though rare in developed countries, it is a common problem in developing countries because illiteracy, lack of health awareness and education, poverty, superstition and prevent women from seeking medical advice during pregnancy. Still eclampsia is one of the leading causes of maternal death in Bangladesh. $^{4}$

Eclampsia is a multisystem disorder, and the pathophysiology is thought to involve cerebral vasospasm leading to ischemia and cerebral edema. ${ }^{1}$ Until recently, the treatment of eclampsia varied throughout the world. The basic principles of management are: (a) control of convulsion, (b) control of hypertension, (c) initiation of steps to effective delivery, and (d) general nursing care. The first goal of management of eclampsia is control of convulsions and stabilization of the patient's basic cardiovascular status. Administration of magnesium sulphate by an established protocol is considered to be the most rapid, efficient and safe pharmacologic approach for accomplishing this goal. ${ }^{7}$

High blood pressure is controlled by injection of hydralazine intravenously followed by oral nifedipine or methyldopa or atenolol. Eclampsia is uniquely a disease of pregnancy, and the only cure is delivery regardless of gestational age. A national therapy for general management, management of hypertension and convulsion has been established in our setup by 'The Eclampsia Working Group of Bangladesh', but controversy exists regarding the obstetric management. ${ }^{7}$

As we do not have adequate facilities for intrapartum management, cesarean section is preferred in many cases, particularly when the fetus is alive, considering the fact that patients and the fetuses may not tolerate the stress of labor. ${ }^{8}$

In Bangladesh, many researchers have worked on eclampsia, but most of the works are related to efficacy, dose and frequency of use of magnesium sulphate. There are only a few works on obstetric management of eclampsia. So, we conducted this study in Eclampsia Unit of Dhaka Medical College Hospital, trying to find out a relatively better mode of delivery for eclampsia patients.

\section{Materials and Methods}

This prospective cohort study was conducted in inpatient (eclampsia unit) department of Obstetrics \& Gynecology, Dhaka Medical College Hospital during the period January to December 2011. Permission for the study was duly obtained from Ethical Committee of Dhaka Medical College \& Hospital.

A total 100 eclamptic women with term pregnancy, live fetus, no other indications for cesarean section or other associated medical disorders were included in the study. Patients were included into two groups. Group I consisted of 50 patients with vaginal delivery and Group II 50 patients with lower segment cesarian section (LSCS). Diagnostic criteria of eclampsia were high blood pressure (>140/90 mm of $\mathrm{Hg}$ ), significant proteinuria and convulsion associated with pregnancy more than 20 weeks of gestation. The purpose and procedure of the study was explained to the subjects who fulfilled the enrollment criteria. After taking informed written consent from the guardians of the patients, history was taken carefully and a thorough clinical examination was done. Then urine was tested (heat coagulation method) for protein. Convulsions were controlled by magnesium sulphate $\left(\mathrm{MgSO}_{4}\right)$ if not contraindicated and blood pressure was controlled by hydralazine, nifedipine or methyldopa. After initial management, decision for termination of pregnancy was taken and mode of delivery (LSCS or vaginal delivery) was planned by the senior obstetrician of the unit. The mode of delivery was carefully noted and the patients were followed-up till discharge or death.

Parameters for fetal and neonatal outcomes were birth weight, APGAR score, live or still births and any complication. Hematuria, pulmonary edema, 
cerebrovascular accident (CVA), renal failure, obstetric shock, abuptio placenta and postpartum hemorrhage (PPH) were considered as maternal complications.

\section{Statistical analysis}

All the relevant data for each patient were recorded in a predesigned data collection sheet. Collected data were compiled and appropriate statistical analyses (Chi-square and unpaired Student's $t$ tests) were done using computer based software, SPSS version 16.0. $\mathrm{P}$ value $<0.05$ was taken as minimum level of significance.

\section{Results}

Table I shows comparison of baseline demographic and clinical characteristics between the two study groups. There was no significant difference in any of the variables.

Maximum number of women in Groups I and II belonged to age group $\leqslant 30$ years $(96 \%$ and $98 \%$ ); mean \pm SD of age was $22 \pm 4.23$ and $21.94 \pm 3.12$ years, respectively. Gestational age was $38.02 \pm 1.19$ and $38.24 \pm 1.36$ weeks in Groups I and II, respectively.

Both in Group I and Group II most of the women were from low socioeconomic status $(80 \%$ and $74 \%)$, primigravida $(72 \%$ and $70 \%$ ), on irregular antenatal care (ANC) $(66 \%$ and $64 \%)$ and had antepartum eclampsia ( $90 \%$ and $96 \%$ ).

Table II shows that there was no significant difference in blood pressure between Group I and Group II. Table III shows comparison of mean \pm SD values of different aspects of convulsion parameters between Group I and Group II. There was no significant difference between the groups. Recurrence of convulsion was significantly high $(\mathrm{P}<0.05)$ in Group I $(30 \%)$ compared to Group II (6\%) (Table IV). Both groups received loading and maintenance doses of $\mathrm{MgSO}_{4}$.
Table I: Comparison of baseline demographic and clinical characteristics between vaginal delivery group (Group I) and cesarean section group (Group II) $(n=100)$

\begin{tabular}{|c|c|c|c|c|c|}
\hline \multirow[t]{2}{*}{ Parameters } & \multicolumn{2}{|c|}{$\begin{array}{l}\text { Group I } \\
(\mathrm{n}=50)\end{array}$} & \multicolumn{2}{|c|}{$\begin{array}{c}\text { Group II } \\
(\mathrm{n}=50)\end{array}$} & \multirow[t]{2}{*}{$P$ value } \\
\hline & Number & Percentage & Number & Percentage & \\
\hline \multicolumn{6}{|l|}{ Age (in years) } \\
\hline$\leqslant 20$ & 28 & 56.0 & 23 & 46.0 & \multirow{6}{*}{${ }^{\mathrm{a}} 0.936^{\mathrm{ns}}$} \\
\hline $21-25$ & 14 & 28.0 & 22 & 44.0 & \\
\hline $26-30$ & 6 & 12.0 & 4 & 8.0 & \\
\hline$>30$ & 2 & 4.0 & 1 & 2.0 & \\
\hline Mean \pm SD & \multicolumn{2}{|c|}{$22 \pm 4.23$} & \multicolumn{2}{|c|}{$21.94 \pm 3.12$} & \\
\hline Range & 17 & & & -32 & \\
\hline \multicolumn{6}{|c|}{ Gestational age (weeks) } \\
\hline$\leqslant 37$ & 24 & 48.0 & 17 & 34.0 & \\
\hline$>37$ & 26 & 52.0 & 33 & 66.0 & \\
\hline Mean \pm SD & \multicolumn{2}{|c|}{$38.02 \pm 1.19$} & \multicolumn{2}{|c|}{$38.24 \pm 1.36$} & \multirow[t]{2}{*}{${ }^{\mathrm{a}} 0.392^{\mathrm{ns}}$} \\
\hline Range & & -40 & & -40 & \\
\hline \multicolumn{6}{|c|}{ Socioeconomic condition } \\
\hline Lower & 40 & 80.0 & 37 & 74.0 & \multirow[t]{2}{*}{${ }^{\mathrm{b}} 0.475^{\mathrm{ns}}$} \\
\hline Middle & 10 & 20.0 & 13 & 26.0 & \\
\hline \multicolumn{6}{|l|}{ Gravida } \\
\hline Primi & 36 & 72.0 & 35 & 70.0 & \multirow{2}{*}{${ }^{\mathrm{b}} 0.825^{\mathrm{ns}}$} \\
\hline Multi & 14 & 28.0 & 15 & 30.0 & \\
\hline \multicolumn{6}{|c|}{ Antenatal check-up } \\
\hline Regular & 9 & 18.0 & 9 & 18.0 & \multirow{3}{*}{${ }^{\mathrm{b}} 0.963^{\mathrm{ns}}$} \\
\hline Irregular & 33 & 66.0 & 32 & 64.0 & \\
\hline None & 8 & 16.0 & 9 & 18.0 & \\
\hline \multicolumn{6}{|l|}{ Urine albumin } \\
\hline Trace $(+)$ & 9 & 18.0 & 6 & 12 & \multirow{4}{*}{$\mathrm{b}_{0.223^{\mathrm{ns}}}$} \\
\hline Mild (++) & 16 & 32.0 & 23 & 46 & \\
\hline Moderate $(+++)$ & 10 & 20.0 & 13 & 26 & \\
\hline Severe $(++++)$ & 15 & 30.0 & 8 & 16 & \\
\hline \multicolumn{6}{|c|}{ Types of eclampsia } \\
\hline Antepartum & 45 & 90.0 & 48 & 96.0 & \multirow[t]{2}{*}{${ }^{b} 0.218^{n s}$} \\
\hline Intrapartum & 5 & 10.0 & 2 & 4.0 & \\
\hline \multicolumn{6}{|c|}{ Consciousness on admission } \\
\hline Conscious & 11 & 22.0 & 4 & 8.0 & \multirow{3}{*}{${ }^{\mathrm{b}} 0.142^{\mathrm{ns}}$} \\
\hline Unconscious & 16 & 32.0 & 20 & 40.0 & \\
\hline Semiconscious & 23 & 46.0 & 26 & 52.0 & \\
\hline
\end{tabular}


Table II: Comparison of blood pressure of the study subjects $(n=100)$

$\begin{array}{ccc}\text { Group I } & \text { Group II } \\ (\mathrm{n}=50) & (\mathrm{n}=50) & \text { P value }\end{array}$

Systolic blood pressure ( $\mathrm{mm} \mathrm{Hg}$ )

\begin{tabular}{|c|c|c|c|}
\hline Mean \pm SD & $162.7 \pm 23.8$ & $162.6 \pm 23.99$ & $0.983^{\mathrm{ns}}$ \\
\hline Range & $120-230$ & $140-220$ & \\
\hline \multicolumn{4}{|c|}{ Diastolic blood pressure (mm Hg) } \\
\hline Mean \pm SD & $102.7 \pm 13.75$ & $103.8 \pm 15$ & $0.703^{\mathrm{ns}}$ \\
\hline Range & $80-130$ & $90-130$ & \\
\hline
\end{tabular}

ns $=$ not significant

$\mathrm{P}$ value reached from unpaired t-test

Table III: Comparison of different aspects of convulsion parameters between vaginal delivery (Group I) and cesarean section (Group II) patients $(\mathrm{n}=100)$

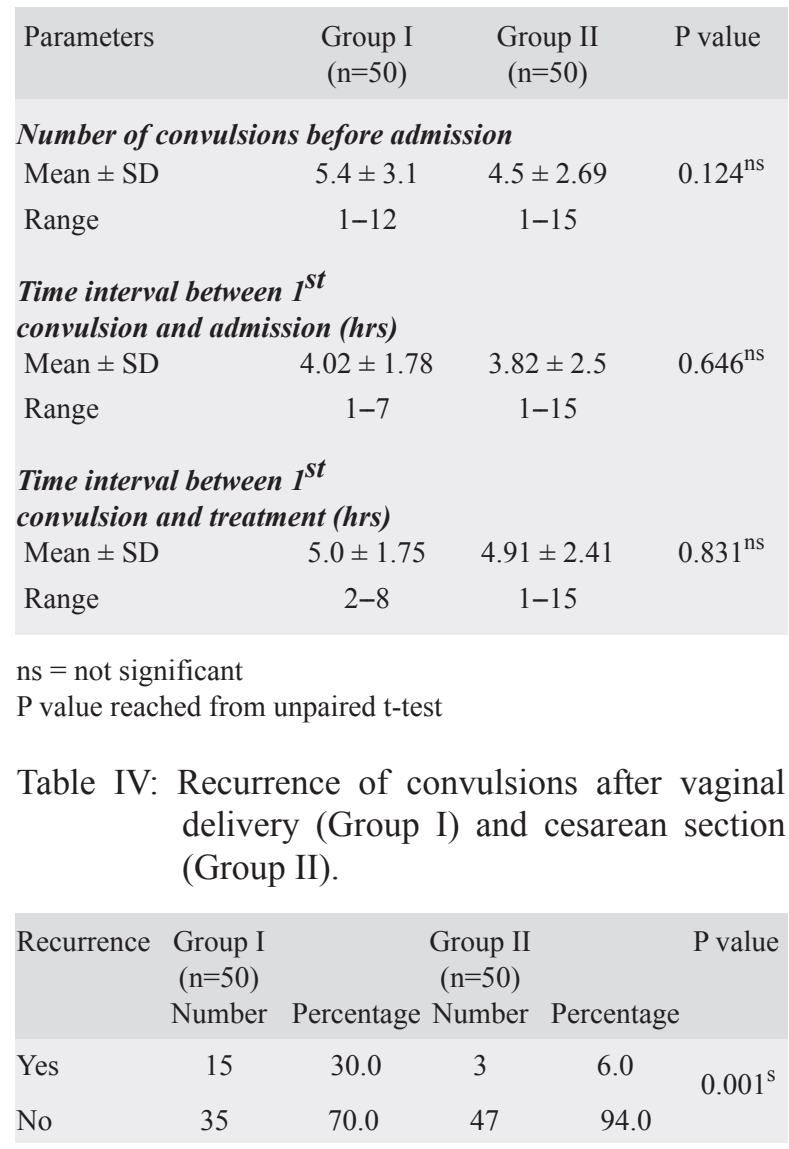

$\mathrm{s}=$ significant

$\mathrm{P}$ value reached from Chi-square test
Table $\mathrm{V}$ shows that maternal complications were significantly higher $(\mathrm{P}<0.001)$ among women in Group I (46\%) compared to Group II (16\%). Table VI shows that different types of maternal complications were higher among vaginal delivery group (Group I) patients than among cesarean section (Group II) patients. Some patients had more than one complications. Maternal mortality was $6 \%$ in Group I and none in Group II. The women died due to cerebrovascular accident (CVA).

Table V: Maternal complications after vaginal delivery (Group I) and cesarean section (Group II)

\begin{tabular}{|c|c|c|c|c|c|}
\hline \multirow[t]{2}{*}{ Complications } & \multicolumn{2}{|c|}{$\begin{array}{l}\text { Group I } \\
(\mathrm{n}=50)\end{array}$} & \multicolumn{2}{|c|}{$\begin{array}{c}\text { Group II } \\
(n=50)\end{array}$} & \multirow[t]{2}{*}{$P$ value } \\
\hline & Number & Percentage & Number & Percentage & \\
\hline No complication & n 27 & 54.0 & 42 & 84.0 & $0.001^{\mathrm{S}}$ \\
\hline Complications & 23 & 46.0 & 8 & 16.0 & \\
\hline
\end{tabular}

Table VI: Types of maternal complications after vaginal delivery (Group I) and cesarean section (Group II)

\begin{tabular}{lcccc} 
Complications & \multicolumn{2}{c}{$\begin{array}{c}\text { Group I } \\
(\mathrm{n}=50)\end{array}$} & \multicolumn{2}{c}{$\begin{array}{c}\text { Group II } \\
(\mathrm{n}=50)\end{array}$} \\
& Number & Percentage & Number & Percentage \\
Hematuria & 7 & 14 & 3 & 6 \\
Pulmonary edema & 4 & 8 & 3 & 6 \\
CVA & 4 & 8 & 1 & 2 \\
Renal failure & 5 & 10 & 1 & 2 \\
Obstetric shock & 3 & 6 & 0 & 0 \\
Abruptio-placenta & 1 & 2 & 0 & 0 \\
PPH & 10 & 20 & 3 & 6
\end{tabular}

Table VII shows no significant difference in mean birth weight of babies between Group I and Group II. One minute APGAR score is better in cesarean section group (5.42) than vaginal delivery group (3.82). Table VIII shows that live births occurred in 94 percent cases in Group II and 80 percent cases in Group I, which is statistically significant. Asphyxia was more in neonates in Group I than in Group II. 
Table VII: Comparison of different neonatal parameters of the study groups $(n=100)$

\begin{tabular}{|c|c|c|c|c|c|}
\hline \multirow[t]{2}{*}{ Parameters } & \multicolumn{2}{|c|}{$\begin{array}{c}\text { Group I } \\
(\mathrm{n}=40)\end{array}$} & \multicolumn{2}{|c|}{$\begin{array}{c}\text { Group II } \\
(\mathrm{n}=47)\end{array}$} & \multirow[t]{2}{*}{$P$ value } \\
\hline & Number & Percentage & Number & Percentag & \\
\hline \multicolumn{6}{|l|}{ Birth weight (kg) } \\
\hline Low birth weight & t 19 & 47.5 & 18 & 38.3 & \\
\hline Normal & 21 & 52.5 & 29 & 61.7 & \\
\hline Mean \pm SD & \multicolumn{2}{|c|}{$2.42 \pm 0.36$} & \multicolumn{2}{|c|}{$2.47 \pm 0.44$} & $0.535^{\mathrm{ns}}$ \\
\hline Range & \multicolumn{2}{|c|}{$1.75-3.6$} & \multicolumn{2}{|c|}{$1.25-3.5$} & \\
\hline \multicolumn{6}{|l|}{ APGAR score } \\
\hline \multicolumn{6}{|l|}{ At $1^{\text {st }}$ minute } \\
\hline$<7$ & 24 & 60.0 & 13 & 27.7 & \\
\hline$\geqslant 7$ & 16 & 40.0 & 34 & 72.3 & \\
\hline Mean \pm SD & \multicolumn{2}{|c|}{$3.82 \pm 2.62$} & \multicolumn{2}{|c|}{$5.42 \pm 2.29$} & $0.016^{\mathrm{s}}$ \\
\hline Range & \multicolumn{2}{|c|}{$2-8$} & \multicolumn{2}{|c|}{$3-9$} & \\
\hline \multicolumn{6}{|l|}{ At $5^{\text {th }}$ minute } \\
\hline$<7$ & 5 & 12.5 & 3 & 6.4 & \\
\hline$\geqslant 7$ & 35 & 87.5 & 44 & 93.6 & \\
\hline Mean \pm SD & \multicolumn{2}{|c|}{$6.84 \pm 2.39$} & \multicolumn{2}{|c|}{$7.16 \pm 2.68$} & $0.561^{\mathrm{ns}}$ \\
\hline Range & \multicolumn{2}{|c|}{$4-10$} & \multicolumn{2}{|c|}{$5-10$} & \\
\hline
\end{tabular}

Table VIII : Fetal outcome among patients undergoing vaginal delivery (Group I) and cesarean section (Group II)

\begin{tabular}{|c|c|c|c|c|c|}
\hline \multirow[t]{2}{*}{ Parameters } & \multicolumn{2}{|c|}{$\begin{array}{c}\text { Group I } \\
(\mathrm{n}=50)\end{array}$} & \multicolumn{2}{|c|}{$\begin{array}{l}\text { Group II } \\
(\mathrm{n}=50)\end{array}$} & \multirow[t]{2}{*}{$\mathrm{P}$ value } \\
\hline & Numb & ercentage & Numb & Percentag & \\
\hline \multicolumn{6}{|c|}{ Fetal outcome } \\
\hline Live birth & 40 & 80.0 & 47 & 94.0 & \multirow{2}{*}{$0.037^{\mathrm{s}}$} \\
\hline Stillbirth & 10 & 20.0 & 3 & 6.0 & \\
\hline \multicolumn{5}{|c|}{$\begin{array}{l}\text { Complication } \\
\text { (among live births) } \quad(\mathrm{n}=40)\end{array}$} & \multirow{3}{*}{$0.001^{\mathrm{s}}$} \\
\hline Asphyxiated & 24 & 60.0 & 11 & 23.4 & \\
\hline None & 16 & 40.0 & 36 & 76.6 & \\
\hline \multicolumn{6}{|c|}{ Referred to ICU (among as- } \\
\hline $\begin{array}{l}\text { Yes } \\
\text { No }\end{array}$ & $\begin{array}{l}9 \\
7\end{array}$ & $\begin{array}{l}56.3 \\
43.8\end{array}$ & $\begin{array}{l}5 \\
6\end{array}$ & $\begin{array}{l}45.5 \\
54.5\end{array}$ & $0.581^{\mathrm{ns}}$ \\
\hline
\end{tabular}

$\mathrm{s}=$ significant, $\mathrm{ns}=$ not significant

$\mathrm{P}$ value reached from Chi-square test

\section{Discussion}

Eclampsia is a well-recognized major cause of maternal and perinatal morbidity and mortality. Though the incidence has fallen considerably in the developed countries, its incidence, morbidity and mortality are still very high in Bangladesh. ${ }^{5}$ In Bangladesh, among the causes of death in women of reproductive age, maternal death contributes $14 \%$ and eclampsia accounts for $20 \%$ of maternal death. ${ }^{4}$ Control of convulsion and management of hypertension are two important parts of the management of eclampsia. There is now conclusive evidence that magnesium sulphate $\left(\mathrm{MgSO}_{4}\right)$ is the best available drug for management of convulsion ${ }^{7}$ and is widely used in different centers of Bangladesh. Once the convulsions are under control, there is universal agreement to deliver the patient regardless of gestational age. The mode is determined by gestational age, condition of the cervix and fetal condition. ${ }^{1}$

The chances of successful induction of labor are low in primigravide with an unfavorable cervix at $<34$ weeks gestation. Even if induction is successful in this group, emergency cesarean section becomes necessary in up to $45 \%$ of cases because of fetal intolerance of labor. A high proportion of such cases are, therefore, delivered by cesarean section without attempt to induction, particularly when delivery needs to be expedited quickly because of concerns about maternal condition. ${ }^{1}$

In our study, both vaginal delivery group and cesarean group patients were compared on important characteristics such as recurrent convulsion, maternal and perinatal morbidity and mortality etc.

In this study, average age was $22 \pm 4.23$ years in vaginal delivery group and $21.94 \pm 3.12$ years in cesarean section group, and most of the patients $(56 \%)$ belonged to $<20$ years age group. In the comprehensive study of Khanam et $\mathrm{al}^{9} 82.7 \%$ of patients were in the age group between 15--25 years. El-Nafaty et $\mathrm{a}^{10}$ also found teenage preponderance $(66.9 \%)$ in the occurrence of eclampsia. Chuni and Khanna ${ }^{11}$ found $36.89 \%$ patients below the age of 20 years. Rouf et $\mathrm{al}^{12}$ found age preponderance between $15-25$ years in $76 \%$ of eclamptic patients. In our study, most of the patients at term had a mean gestational age of 38 weeks. This corresponds with the other studies. ${ }^{10,12}$ 
In our study $80 \%$ patients of vaginal delivery group and $74 \%$ patients of cesarean section group were from low socioeconomic status. Study done by Chowdhury ${ }^{13}$ has shown that $95 \%$ patients belonged to low socioeconomic group and $73.5 \%$ of patients in the study of El-Nafaty et al. ${ }^{10}$ On an average $17 \%$ of patients in our study did not receive any antenatal care which was $35.57 \%$ in the Khanam et $\mathrm{al}^{9}$ study and $69.2 \%$ in the El-Nafaty series. ${ }^{10}$

The two groups of patients were also matched with regard to blood pressure and proteinuria and consciousness level. Most of the patients of both groups presented with anteparturn eclampsia in unconscious or semiconscious state, which is similar to the another study. ${ }^{9}$

Recurrence of convulsion was $30 \%$ in vaginal delivery group and $6 \%$ in the cesarean section group. This rate is similar to the study of Onuh and Aisien ${ }^{14}$ showing a recurrence rate of $4.8 \%$ in the cesarean section group. Number of convulsions before admission was $4.40 \pm 1.51$ (in vaginal delivery group) versus $4.84 \pm 2.20$ (in cesarean section group). This is similar to the findings of Ikechebelu and Okoli. ${ }^{15}$ Convulsions occurred in 55.8\% patients after the 37 th week in the study of Khanam et al. ${ }^{9}$

In this series, maternal complications were more in vaginal delivery group. CVA and pulmonary edema developed in $8 \%$ cases. In cesarean section group, it was about $2 \%$ and $6 \%$ respectively. In the study of Begum et $\mathrm{al}^{5}$ both pulmonary edema and CVA were found to be more in the vaginal delivery group (22\% and $12 \%$ of patients respectively). This corresponds with some other studies. ${ }^{5,16}$ In the study of Khanam et $\mathrm{al}^{9}$ the major complications like pulmonary edema, HELLP syndrome, DIC, renal failure and obstetric shock were similar to the findings in our study.

Renal failure occurred in $21.7 \%$ of vaginal delivery patients in our study and it was two percent in the study of Begum et al. ${ }^{4}$ Six percent of the vaginal delivery group patients died from CVA. No patient died in the cesarean section group in our study. The maternal mortality was $5 \%$ in both groups in the study by Chowdhury ${ }^{13}$ and $4 \%$ in the study by Begum. ${ }^{8}$ Pulmonary edema and CVA were two common causes of the death.
Regarding fetal outcomes, a higher number (20\%) of babies were born stillbirth in vaginal delivery group as against six percent in the cesarean section group. Most of the babies had low birth weight. Mean birth weight was $2.42 \mathrm{~kg}$ in vaginal and $2.47 \mathrm{~kg}$ in cesarean section groups. APGAR score in 1st minute was $5.42 \pm 2.29$ in cesarean section group which was better than in vaginal delivery group. Jahan $\mathrm{A}^{17}$ has shown almost similar findings. Birth asphyxia was higher in vaginal delivery group in our study (60 percent as against 23.4 percent in the cesarean section group). A higher number of babies were treated in neonatal care unit (NCU) from vaginal delivery group. Perinatal mortality has been found to be higher in vaginal delivery group in many studies in this country. 8,13

Ikechebelu and Okoli ${ }^{15}$ have reported in their series a high cesarean section rate of 85.7 percent among eclamptic patients. Other studies carried out by Ogunniyi et al ${ }^{18}$ and Chama et al ${ }^{19}$ also revealed high cesarean section rates ranging between 50 percent to 76.5 percent. Arora et $\mathrm{al}^{20}$ have advocated early cesarean section in eclamptic patients, at least in the referral centers. This is because they found in their series a maternal mortality of 4.3 percent in the cesarean section group, which is almost half the mortality rate of 7.1 percent in the vaginal delivery group. Moreover, El-Nafaty ${ }^{10}$ in his series found a perinatal mortality rate of 25.6 percent in the cesarean section group, which is also about half the perinatal mortality of 47.7 percent in the vaginal delivery group. Jahan $\mathrm{A}^{17}$ has shown almost similar findings.

It is observed in this study that the patients undergoing cesarean section showed a better maternal outcome with fewer incidences of recurrent convulsions and other maternal complications than vaginal delivery group. Regarding fetal outcome, the number of stillbirths and asphyxiated baby was less in the cesarean section group than that in the vaginal delivery group; the result being statistically significant. So the result of the study shows a better feto-maternal outcome in the cesarean section group than in the vaginal delivery group.

\section{References}

1. Robson SC. Hypertension and renal disease in pregnancy. In: Edmonds DK (ed). Dewhurst's textbook of obstetrics and gynaecology for postgraduates. $6^{\text {th }}$ edn. London: Blackwell Science Ltd., 2000: 166-185. 
2. Hypertensive disorders in pregnancy. In: Arias F, Daftary SN, Bhide AG (eds). Practical guide to high-risk pregnancy \& delivery: a south Asian perspective. $3^{\text {rd }}$ edn. New Delhi: Elsevier, 2008: 397-439.

3. Reynolds C, Mabie WC, Sibai BM. Hypertensive states of pregnancy. In: Decherney AH (ed). Current obstetrics and gynaecologic diagnosis and treatment. $9^{\text {th }}$ edn. New York: Lange Medical Book, 2003: 338-353.

4. Bangladesh maternal mortality and health care survey (BMMS) 2010. ICDDRB \& NIPORT, September 2011

5. Begum MR, Begum A, Quadir E, Akhter S, Shamsuddin L. Eclampsia: still a problem in Bangladesh, Med Gen Med 2004: 6-7.

6. Yasmin HA, Rahman MH, Chowdhury FK. Baseline survey for assesment of emergency obstetrics care services in Bangladesh: Bangladesh Institute of Research for Promotion of Essential and Reproductive Health and Technologies (BIRPERHT); 1995: 10.

7. The Eclampsia Working Group. Eclampsia in Bangladesh: a review and a guideline. Bangladesh J Obstet Gynaecol 1997; 12: 1-27.

8. Begum A. Role of caesarean section affecting the foetomaternal outcome in eclampsia [FCPS Dissertation]. Dhaka: Bangladesh College of Physicians and Surgeons; 2005.

9. Khanam K, Akhter S, Begum A. Maternal outcome in eclampsia: a review of 104 cases. JOPSOM 2005; 24: 9-14.

10. El-Nafaty AU, Melah GS, Massa AA, Audu BM, Nelda $\mathrm{M}$. The analysis of eclamptic morbidity and mortality in the Specialist Hospital Gombe, Nigeria. J Obstet Gynaecol 2004; 24: 142-147.
11. Chuni N, Khanna S. Risk factors in relation to eclampsia in Nepal. Int J Gynecol Obstet 2004; 87: 159-160.

12. Rouf S, Shamsuddin L, Khan JR. Magnesium sulphate versus diazepam in the management of eclampsia. Bangladesh J Obstet Gynaecol 1996; 11: 1-14.

13. Chowdhury ML. Role of caesarean section in improving fetomaternal outcome in eclampsia [FCPS Dissertation]. Dhaka: Bangladesh College of Physicians and Surgeons; 1998.

14. Onuh SO, Aisien AO. Maternal and foetal outcome in eclamptic patients in Benin City, Nigeria. J Obstet Gynaecol 2004; 24: 765-768.

15. Ikechebelu JI, Okoli CC. Review of eclampsia at the Nnamdi Azikiwe. University teaching hospital, Nnewi (January1996-December 2000). J Obstet Gynaecol 2002; 22: 287-290.

16. Coppage KH, Polzin WJ. Severe preeclampsia and delivery outcomes: is immediate cesarean delivery beneficial? Am J Obstet Gynecol 2002; 186: 921-923.

17. Jahan A. Maternal and fetal outcome of caesarean secion and vaginal delivery in eclampsia patients-a comparative study [FCPS Dissertation]. Dhaka: Bangladesh College of Physicians and Surgeons; 2006.

18. Ogunniyi SO, Sanusi YO, Ogunniyi FA. Eclampsia: a continuing obstetric catastrophe, the experience in Ille1lfe, Nigeria. J Obstet Gynecol1999; 19: 26-29.

19. Chama CM, El-Nafty AL, Idrisa A. Caesarean morbidity and mortality at Maiduguri, Nigeria. J Obstet Gynecol 2002; 20: 45-48.

20. Arora R, Swain S, Agrawal A, Habeebullah S. Impact of mode of delivery on maternal mortality in eclampsia. $\mathrm{J}$ Indian Med Assoc 1997; 9: 103-104. 